\title{
Performance of Aerobic Granular Sludge in Treating Soy Sauce Wastewater at Different Hydraulic Retention Time
}

\author{
Hasnida Harun 1, , Hazren A. Hamid ${ }^{2}$, Norshuhaila Mohamed Sunar ${ }^{3}$, Faridah Hanim Ahmad ${ }^{4}$, Aznah Nor Anuar $^{5}$, \\ Noor Hasyimah Rosman ${ }^{6}$, Inawati Othman ${ }^{7}$ \\ ${ }^{I}$ Advanced Technology Centre (ATC), Faculty of Engineering Faculty of Technology, Universiti Tun Hussein Onn, 84600 Pagoh, Johor, \\ Malaysia \\ ${ }^{2}$ Department of Environment and Green Technology, Malaysia-Japan International Institute of Technology (MJIIT), Universiti \\ Teknologi Malaysia, 54100 Kuala Lumpur, Malaysia \\ ${ }^{3}$ Department of Environmental Engineering, Faculty of Civil Engineering, Universiti Teknologi Malaysia, 81310, Skudai, Johor, \\ Malaysia \\ *Corresponding authorE-mail: hasnidah@uthm.edu.my
}

\begin{abstract}
Aerobic granular sludge had shown its capability in treating soy sauce wastewater, but its reactor performance, granules properties and biokinetics in different hydraulic retention times (HRT) is still unknown. To ensure the reactor is performed in optimum condition, a judicially selection of HRT is important. The study was conducted in a high and slender column operated according to a sequential batch reactor (SBR) with a sequence of aerobic and anaerobic/anoxic reaction phases. Three different HRTs $(8,16,24 \mathrm{~h})$ and different anaerobic and aerobic reaction time were evaluated. In the study demonstrated the increase in HRT could reduce the organic loading rate (OLR) as well as biomass yield $\left(\mathrm{Y}_{\mathrm{obs}}, \mathrm{Y}\right)$, endogenous decay rate $\left(\mathrm{k}_{\mathrm{d}}\right)$ and overall specific biomass growth rate $\left(\mu_{\text {overall }}\right)$. It was observed a slight increase in the mixed liquor suspended solid (MLSS) and the granules mean size as the OLR decreased. Meanwhile, in the lowest HRT reactor, a narrow diameter range of aerobic granule from 3 to $100 \mu \mathrm{m}$ was observed due to the development of small and dense granules. The HRT of $24 \mathrm{~h}$ with aerobic and anaerobic/anoxic reaction time of 3.88 and $7.77 \mathrm{~h}$ respectively is the SBR's best performances due to the improvement of the aerobic granular physical properties.
\end{abstract}

Keywords: Aerobic granular sludge, Biokinetics, Hydraulic retention time, SBR, Soy sauce wastewater

\section{Introduction}

In general, soy sauce wastewater has high COD, BOD, total suspended solid (TSS), protein and has deeper colour due to the fermentation process, that contribute to the strong odours during wastewater treatment [1]. In the effort of designing an effective treatment system for soy sauce wastewater, many researches have conducted their studies on the topic, which include using the sequencing batch reactor (SBR) system. As such, a compact bioreactor of aerobic granular sludge technology based on SBR system is recommended to reduce the reactor volume and shorten the retention time by providing a good solid-liquid separation packed with microbial communities in a single reactor [2].

Besides, a literature has reported the ability of aerobic granular sludge for treating soy sauce wastewaters, which involves both anaerobic and aerobic processes in SBR [3]. To meet a complete degradation process in treating recalcitrant compounds especially, the combination process of anaerobic and aerobic condition is necessary [4]. However, as the wastewater treatment system develop, a need to develop an efficient nutrient removals system especially in treating high strength organic wastewater to provide good sanitation is crucial.

Significantly, HRT was found to be an important key parameter, which can improve the removal rates of all targeted substances especially in SBR [5]. As identified by Pan et al. [6], short HRT and relatively high OLR in a treatment system is favourable for the aerobic granular sludge formation. This is because short HRT in a system causes wash out of the poor settling biomass, while high OLR ensures the growth of retained biomass in the system. Basically, the microorganisms in the SBR system experienced a hydraulic selection pressure due to the reactor configuration such as HRT, which required the biomass either being washed out or retained in the system to be bound together to form good settleability granules [7].

However, as the HRT is known to have remarkable influent on the aerobic granular sludge development, the present study aimed to determine the HRT relationship with the aerobic granular sludge's performances for treating soy sauce wastewater, besides monitoring the capability of soy sauce wastewater as the substrate media for cultivating the granular sludge under certain HRT. As the studies on the aerobic granulation kinetic behaviour in utilizing substrate at different HRTs would show different behaviour of aerobic granulation kinetics [8], the granules properties, reactor performance, and biokinetics changes are examined.

\section{Materials and Methods}

Fig. 1 is a flowchart illustrating the overall outline of the experimental work for this study. 


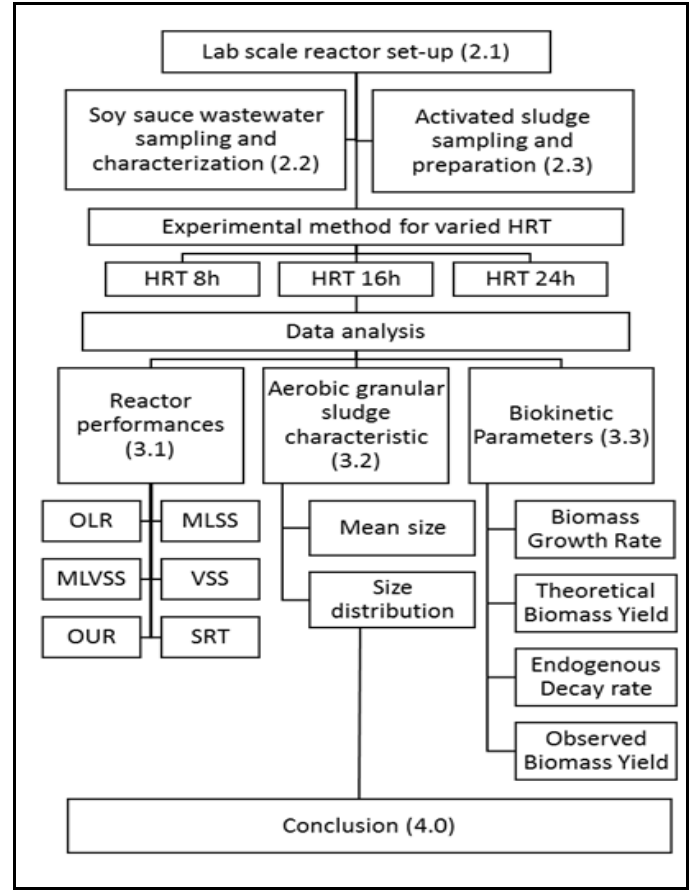

Fig.1: Flowchart of the experimental work.

\subsection{Reactor Set-Up}

A SBR (100 cm in height, $6.5 \mathrm{~cm}$ in diameter) with working volume of $3 \mathrm{~L}$ was used in this study. The influent was supply at the bottom of the reactor and the effluent was discharged via an outlet port positioned at mid-height of the reactor column, yielding a $50 \%$ of volumetric exchange ratio. A timer box was installed to control the pumps; influent, effluent, circulator and aerator in the reactor. An air bubble diffuser was placed at the bottom of the reactor. Fig. 2 shows the schematic drawing of the reactor set-up.

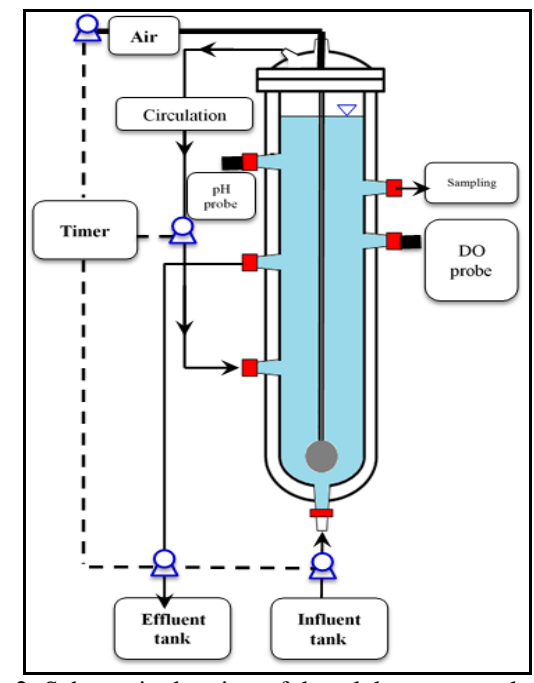

Fig. 2: Schematic drawing of the a laboratory scale SBR

\subsection{Wastewater Characteristics}

The soy sauce wastewater sample was taken from a soy sauce factory located at Johor Bahru, Malaysia. It was sampled weekly and stored in cold storage room at a temperature of $4{ }^{\circ} \mathrm{C}$ to prevent the wastewater to biodegrade by the microbial action. The soy sauce wastewater contains a small amount of chili flakes, uncrushed soybean, inorganic and organic salts and also grey water from washings activities. These substances are readily biodegradable and it will result in high oxygen consumption upon discharge of wastewater in receiving surface water which which contributed to high level of COD, BOD and suspended solid (SS)
The characteristics of the soy sauce wastewater was as follows: COD, $7620 \pm 80.4 \mathrm{mg} / \mathrm{L}$; BOD, $4967 \pm 566 \mathrm{mg} / \mathrm{L}$; total suspended solids (TSS), $4230 \mathrm{mg} / \mathrm{L}$; total solid (TS), $13900 \mathrm{mg} / \mathrm{L}$ and $\mathrm{pH}$, $6.3-7.5$.

\subsection{Seed Sludge Preparation}

The reactor was inoculated with $1.5 \mathrm{~L}$ of freshly activated sludge, collected from an aeration tank of Municipal Wastewater Treatments Plants, Johor Bahru, Malaysia. The sludge was sieved to pass $1.0 \mathrm{~mm}$ mesh to remove debris and small particles. The sludge was acclimatized with mixed wastewater of domestic and soy sauce for a week. The activated sludge was loose and fluffy with mixed liquor suspended solid (MLSS) is $23.9 \pm 2.9 \mathrm{~g} / \mathrm{L}$ and the sludge volume index (SVI) is $120-150 \mathrm{ml} / \mathrm{g}$.

\subsection{Analytical Methods}

Sample analysis included MLSS, mixed liquor volatile suspended solid (MLVSS), COD, BOD, SS and TS, all according to Standard Methods [9]. MLVSS was determined by ashing the dry sample at $550^{\circ} \mathrm{C}$ in a furnace for $15 \mathrm{~min}$. The $\mathrm{pH}$ and DO were continuously monitored with the electro probe sensors inserted in the reactor and recorded by a $\mathrm{pH} / \mathrm{DO}$ meter (Orion 3-Star Benchtop pH/DO Meter). The granules developed in the reactor were analyzed for their physical characteristics: the granules diameter and the granules size distribution. The morphological and structural observations of granular sludge were conducted periodically by using a stereo microscope equipped with digital image analyzer (PAX- ITv6, ARC PAX-CAM). The particular size distribution of the granules was measured using the laser particle size analysis system (Mastersizer 3000, Malvern instruments). The formulas and calculations for kinetic parameters included the theoretical biomass yield $(\mathrm{Y})$, observed biomass yield $\left(\mathrm{Y}_{\mathrm{obs}}\right)$, endogenous decay rate $\left(\mathrm{k}_{\mathrm{d}}\right)$, and overall specific biomass growth rate $\left(\mu_{\text {overall }}\right)$, and were referred Muda et al. [10] and Rojas et al. [11].

\subsection{Experimental Procedures}

The reactor operation mode was based on SBR system. The system cycle time consists of fil (5 min), anaerobic/anoxic (146 $466 \mathrm{~min})$, aerate $(73-233 \mathrm{~min})$, settle (10 min), discharge (5 min) and idle $(1 \mathrm{~min})$ stages. Air was supplied by an air pump at 2 $\mathrm{L} / \mathrm{min}$ volumetric flow rate throughout the aeration stage. The wastewater in the reactor was allowed to circulate using peristaltic pump (ColeeParmer System Model, 6-600 rpm) at $18 \mathrm{~L} / \mathrm{h}$ flow rate during the anaerobic/anoxic stage. The details of the experimental conditions are shown in Table 1. The HRT was varied between 8 and $24 \mathrm{~h}$ in three reactors namely R1, R2 and R3. The OLR was varied based on the operated HRT. The reactor was operated at room temperature $\left(27 \pm 1{ }^{\circ} \mathrm{C}\right)$ while the $\mathrm{pH}$ throughout the experiment was between 7.0 and 8.0.

Table 1: Detailed experiment conditions for the reactor system

\begin{tabular}{|l|c|c|c|c|c|}
\hline Reactor & $\begin{array}{c}\text { Cycle } \\
\text { time } \\
(\mathrm{h})\end{array}$ & $\begin{array}{c}\text { Aeration } \\
(\mathrm{h})\end{array}$ & $\begin{array}{c}\text { Anaerobic/ } \\
\text { anoxic (h) }\end{array}$ & $\begin{array}{c}\text { HRT } \\
(\mathrm{h})\end{array}$ & $\begin{array}{c}\text { OLR } \\
\left(\mathrm{kgCOD} / \mathrm{m}^{3} / \mathrm{day}\right)\end{array}$ \\
\hline R1 & 4 & 1.22 & 2.43 & 8 & $14.7-40.8$ \\
\hline R2 & 8 & 2.00 & 5.68 & 16 & $1.7-26.3$ \\
\hline R3 & 12 & 3.88 & 7.77 & 24 & $4.9-13.7$ \\
\hline
\end{tabular}

\section{Result and Discussion}

\subsection{Physical Profile of the Reactor System}

During the operation, monitoring the concentration of biomass is important to ensure the active biomass in the reactor is adequate for completing the degradation process, especially for a system deals with a wide range of OLR [12]. The solid retention time 
(SRT) of a system represents the average detention time of the biomass and controlled operationally by the biomass concentration. The SRT of R1, R2 and R3 was determined at the end of every experiments in this study, as shown in Table 2 . In the reactor that applied $24 \mathrm{~h}$ of HRT had $8.53 \pm 1.8$ days of SRT which is the longest, followed by $3.06 \pm 1.1$ days in R2 and shortest SRT showed in R1 (1.67 \pm 0.6 days). It was found that the SRT in the reactor system was proportionally related to the HRT applied.

According to Liu and Liu [13], the SRT in a reactor system influences the growth rate of microorganisms, which is important in designing an aerobic granular sludge system. The longer SRT applied in a system would lower the specific bacteria growth rate. Therefore, the operation strategy of short SRT was applied in the aerobic granular sludge technology to fasten the bacteria growth rate to enhance the granulation process. Furthermore, the performances of a reactor system in utilized nitrification and COD are also influenced by the SRT [14]. This is because the optimum SRT allowed the bacteria to grow faster and a stable population would developed for the biochemical transformation process [15].

Table 2: The physical properties of the reactors at different HRTs.

\begin{tabular}{|c|c|c|c|}
\hline Reactor & R3 & $\mathbf{R 2}$ & R1 \\
\hline HRT (h) & 24 & 16 & 8 \\
\hline $\begin{array}{l}\text { OLR } \\
\left(\mathrm{kgCOD} / \mathrm{m}^{3} / \text { day }\right)\end{array}$ & $4.9-13.7$ & $1.7-26.3$ & $14.7-40.8$ \\
\hline $\operatorname{MLSS}(\mathrm{g} / \mathrm{L})$ & $12.22 \pm 0.87$ & $9.97 \pm 0.25$ & $11.23 \pm 0.99$ \\
\hline MLVSS (g/L) & $10.9 \pm 1.2$ & $8.53 \pm 0.7$ & $10.6 \pm 0.9$ \\
\hline $\mathrm{VSS}_{\text {effluent }}(\mathrm{g} / \mathrm{L})$ & $3.93 \pm 0.1$ & $1.67 \pm 0.3$ & $1.8 \pm 0.1$ \\
\hline OUR $\left(\mathrm{mgO}_{2} / \mathrm{L} / \mathrm{h}\right)$ & $4.87 \pm 0.14$ & $10.47 \pm 1.66$ & $17.17 \pm 1.54$ \\
\hline SRT (d) & $8.53 \pm 1.8$ & $3.06 \pm 1.1$ & $1.67 \pm 0.6$ \\
\hline
\end{tabular}

OUR in the reactors were determined at the last 10 minutes before the aeration stage was stopped. The OUR represents the growth activities of heterotrophic and autotrophic [16]. From the result, the OUR value increased when the HRT decreased due to the increased OLR. According to Obaja et al. [17], the OUR is higher as the substrate is higher in the system because of the higher viable biomass activity. This proven in this study when R1 with 8 $\mathrm{h}$ of HRT was supplied with the highest OLR $(14.7-40.8$ $\mathrm{kgCOD} / \mathrm{m}^{3} /$ day) achieved the highest OUR (17.17 \pm 1.54 $\left.\mathrm{mgO}_{2} / \mathrm{L} / \mathrm{h}\right)$. The lower OUR value in the system indicated that the degradation of external substrate. As the substrate was completely consumed and degraded, the biomass was in a starvation condition and the endogenous respiration occurs [10]. According to $\mathrm{Ni}$ and $\mathrm{Yu}$ [16], the maximum OUR of $350 \mathrm{mg} \mathrm{O} / \mathrm{L} / \mathrm{h}$ is the combined oxygen uptake capacity from both heterotrophs and autotrophs. 75 $\mathrm{mgO}_{2} / \mathrm{L} / \mathrm{h}$ is the maximum OURs for the autotrophs and approximately $275 \mathrm{mg} \mathrm{O}_{2} / \mathrm{L} / \mathrm{h}$ are heterotrophs. From the $\mathrm{Ni}$ et al. [18] study, the total oxygen was consumed by the heterotrophs is $61 \%$, while the autotrophs consume only $39 \%$ in the reactor.

\subsection{Physical Characteristics of Aerobic Granular Sludge}

The physical characteristics of aerobic granular sludge had affected by HRT and OLR of a reactor [19]. All the three reactors were successful in developing aerobic granular sludge. However, the structural features and morphology of aerobic granular sludge produced were different at different HRTs. R1 was operated with $8 \mathrm{~h}$ of HRT developed smaller aerobic granular sludge with mean diameter of $0.8 \pm 0.2 \mathrm{~mm}$ and become more compact than granules in R2 and R3. The aerobic granular sludge in R3 had the highest mean diameter of $2.2 \pm 0.1 \mathrm{~mm}$, while aerobic granular sludge grew into $1.3 \pm 0.7 \mathrm{~mm}$ in $\mathrm{R} 2$ on day 63 operation. The mean diameter of granules appeared to be correlated with the HRT. The result indicates that HRT is one of the effective operating parameter that control the granules size in a reactor. In the lowest HRT, the mean size of aerobic granular sludge in R1 was the smallest compared to other reactors. According to Rosman et al. [19], lower HRT would enhance the extracellular polymeric substances (EPS) production. A higher hydraulic selection pressure is due to the shortest cycle time applied to the system. The EPS production could facilitate both cohesion and adhesion of cells and play a crucial role in develop and maintaining structure integrity in an immobilized cells community. Meanwhile, the size of aerobic granular sludge in R3 was the largest compared to other reactors. The growth of the largest aerobic granular sludge size in $24 \mathrm{~h}$ of HRT was due to the loosely linked microbes within the granules and existed of cavities become the granules less dense. In addition, $24 \mathrm{~h}$ of HRT in R3 resulted the system encounter the longest cycle time. Therefore, a weak hydraulic selection pressure on the biomass was served in the system. This is because the frequency of dispersed and filamentous particles being discharged through the effluent withdrawal is lesser. Therefore, the excessive filamentous microorganisms was retained and survived in the system, resulting in sloughing detachment of the particles and producing big aggregates [20]. Hence, the filamentous organism's entanglement might increase the size of granule rapidly but loosely. This reason might also account for the largest aerobic granular sludge size developed in R3 for only 63 days operation time compared to other reactors. The development of large granules were not stable, which became loose and then gradually disintegrated [21].

Interestingly, the particle size distribution measurements show a clear impact of the HRTs on the granule size. Aerobic granular sludge size distribution at different HRTs of $8 \mathrm{~h}, 16 \mathrm{~h}$ and $24 \mathrm{~h}$ shown in Fig.3. In R1, a narrow diameter range from 3 to $100 \mu \mathrm{m}$ was observed under the lowest HRT (i.e. $8 \mathrm{~h}$ ). This is due to the development of small and dense aerobic granular sludge. Moreover, the granules size followed the dynamic population balance, which is the simultaneous breakage and granulation mechanisms, where higher granulation ability and strength integrity of aerobic granules will benefit in developing the larger granules size [22]. There are two peaks were observed in the particle size distribution under $16 \mathrm{~h}$ of HRT. One peak at mean size of $100 \mu \mathrm{m}$ and another peak at mean size of $1300 \mu \mathrm{m}$, which indicated that small granules still coexisted with the large granules in the $\mathrm{R} 2$ even after the mean granules size grew bigger.

Therefore, a wide diameter range of aerobic granular sludge existed in R2 with 4 to $3080 \mu \mathrm{m}$. Meanwhile, in R3 with the highest HRT of $24 \mathrm{~h}$, almost $10 \%$ of aerobic granular sludge volume was from size of $1500 \mu \mathrm{m}$. The reactor also shows a wide range of granules size which is from 5 to $3080 \mu \mathrm{m}$, which mean granulation is a gradual process of small size of seed sludge developed into stables and large granules [23]. In addition, too long HRT caused more flocculent sludge retained in the system with slow growth rate of the microorganisms, which became a disadvantage to the biomass aggregation. As explained by Pan et al. [6], an optimum HRT operated in a reactor might lead to a rapid granulation process and maintained the stabilization of granular sludge with enhanced high microbial activities.

\subsection{Biokinetics Parameter}

Muda et al., [10] proposed that the substrate degradation rate and biomass production process that influenced the biomass concentration in a system is known as the kinetic parameters. In this study, the kinetic study was performed at OLR of 4.9-13.7, $1.7-26.3$ and $14.7-40.8 \mathrm{~kg} \mathrm{COD} / \mathrm{m}^{3} /$ day with 24,16 , and $8 \mathrm{~h}$ of HRT, respectively. The applied parameters were obtained at the end of experiment for each HRT. SRT is the one of the most critical parameters to evaluate the reactor performance and to determine the kinetic value [24]. The value of SRT for 24, 16, and $8 \mathrm{~h}$ of HRT was $8.53,3.06$ and 1.67 days respectively. Table 3 showed the results of the kinetic parameters for every HRT. 

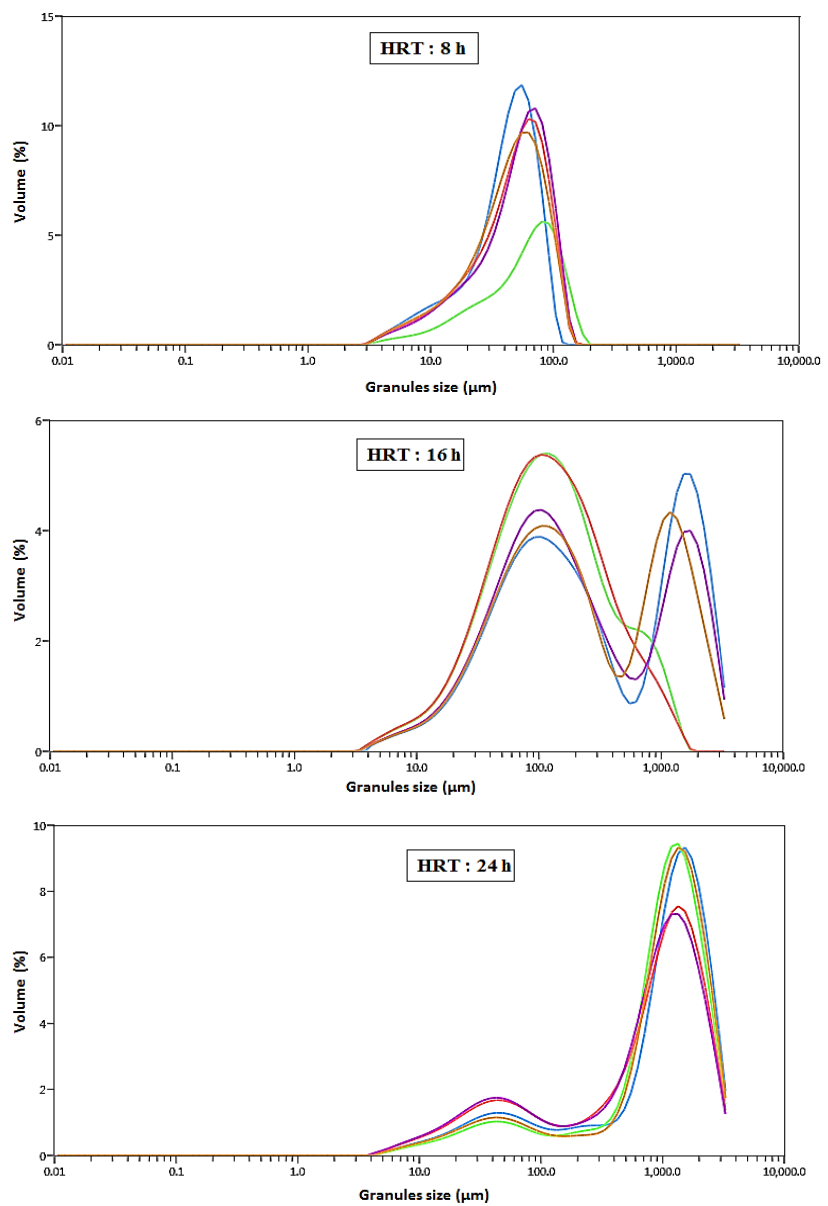

Fig. 3: Aerobic granular sludge size distribution at different HRTs of $8 \mathrm{~h}$, $16 \mathrm{~h}$ and $24 \mathrm{~h}$.

The increased of SRT demonstrated the decrease of $\mu_{\text {overall }}$ in the reactor system. It explains that the longest period of HRT led to the slowest $\mu_{\text {overall }}$ since the biomass was exposed to the longest period of endogenous respiration or decaying [25]. As reported by Moy et al. [26] and Zheng et al. [27], lower $\mu_{\text {overall }}$ and longer SRT allowed the aerobic granular sludge to withstand high OLR and maintain structural stability. The biomass decay rate $\left(\mathrm{k}_{\mathrm{d}}\right)$ is the biomass loss rate during the endogenous respiration [25]. $0.203 \mathrm{~d}^{-1}$ is the highest value of $k_{d}$ in R3 with the highest HRT (i.e. $24 \mathrm{~h}$ ). The highest value of $\mathrm{k}_{\mathrm{d}}$ represent the highest decay rate of biomass. Since the OLR in R3 with $24 \mathrm{~h}$ of HRT was low, the biomass activity become limited as the OUR value was low (13.75 $\pm 0.37 \mathrm{mgO}_{2} / \mathrm{L} / \mathrm{h}$ ) and lead to the high biomass loss. Compared to these results, Gao et al. [28] reported lower $\mathrm{k}_{\mathrm{d}}$ with $0.006-0.027 \mathrm{~d}$ ${ }^{1}$ was achieved.

According to Soltani et al. [24], observed biomass yield ( $\left.\mathrm{Y}_{\mathrm{obs}}\right)$ is an important parameter that represents the ratio of biomass production to the mass of substrate consumed. $\mathrm{Y}_{\mathrm{obs}}$ explains the sludge productivity in the reactor system. From the observation, $\mu_{\text {overall }}$ and $\mathrm{Y}_{\mathrm{obs}}$ were closely related to the OLR of the reactor, while the OLR relied on the operated HRT. The theoretical biomass yield (Y) is derived from $\mathrm{Y}_{\mathrm{obs}}$ and the difference is due to the variation of mechanisms, such as biomass endogenous metabolism, predation, death and decay rate, which are represented by $k_{d}$ [29]. From the result, increased of the SRT from 1.67 to $8.53 \mathrm{~d}$ shows the decreasing of $\mathrm{k}_{\mathrm{d}}$ value from 0.046 to $0.013 \mathrm{~d}^{-1}$, respectively. As the highest OLR (14.7-40.8 $\mathrm{kgCOD} / \mathrm{m}^{3} /$ day) supplied in the system, the $\mathrm{k}_{\mathrm{d}}$ value increased. Muda et al. [10] also experienced the same trend but the $\mathrm{k}_{\mathrm{d}}$ value achieved was lower than this study. From the result, the biomass loss rate in the $24 \mathrm{~h}$ of HRT was $0.013 \mathrm{~d}^{-1}$, followed by $16 \mathrm{~h}$ of HRT with $0.035 \mathrm{~d}^{-1}$ and $0.046 \mathrm{~d}^{-1}$ in $8 \mathrm{~h}$ of HRT. The biomass loss rates reported by Muda et al. [10] were lower than achieved in this study by with 0.0096 to $0.0060 \mathrm{~d}^{-1}$ of the $\mathrm{k}_{\mathrm{d}}$ value.

Table 3: Kinetic coefficients of aerobic granular sludge at different HRTs.

\begin{tabular}{|c|c|c|c|}
\hline \multirow{2}{*}{ Kinetic parameters } & \multicolumn{3}{|c|}{ HRT } \\
\hline & $24 h$ & $16 \mathrm{~h}$ & $8 h$ \\
\hline OLR $\left(\mathrm{kgCOD} / \mathrm{m}^{3} /\right.$ day $)$ & $4.9-13.7$ & $1.7-26.3$ & $14.7-40.8$ \\
\hline SRT (d) & 8.53 & 3.06 & 1.67 \\
\hline OUR $\left(\mathrm{mgO}_{2} / \mathrm{L} / \mathrm{h}\right)$ & $\begin{array}{c}4.87 \pm \\
0.14\end{array}$ & $\begin{array}{c}10.47 \pm \\
1.66\end{array}$ & $17.17 \pm 1.54$ \\
\hline $\begin{array}{l}\text { Observed specific biomass } \\
\text { growth rate, } \mu_{\text {ovam }}\left(\mathrm{d}^{-1}\right)\end{array}$ & 0.117 & 0.277 & 0.599 \\
\hline Biomass decay rate, $\mathrm{k}_{\mathrm{g}}\left(\mathrm{d}^{-1}\right)$ & 0.013 & 0.035 & 0.046 \\
\hline $\begin{array}{l}\text { Observed biomass yield, } Y_{\text {dex }} \\
\text { (mgVSS/mgCOD) }\end{array}$ & 0.338 & 0.371 & 0.865 \\
\hline $\begin{array}{l}\text { Theoretical biomass yield, } Y \\
\text { (mgVSS/mgCOD) }\end{array}$ & 0.374 & 0.417 & 0.932 \\
\hline
\end{tabular}

The sludge production in the R1 (i.e. $8 \mathrm{~h}$ HRT) was the highest compared to other reactors. This can be seen by the highest $\mathrm{Y}_{\mathrm{obs}}$ value obtained in the system with $8 \mathrm{~h}$ of HRT and can be related to the highest biomass in the effluent $(2.27 \mathrm{MLVSSg} / \mathrm{L})$ was being washout from the R1 and less amount of substrate was being utilized. Therefore, there are less sludge production from the R3 with $24 \mathrm{~h}$ of HRT and R2 (16 h of HRT) as the $\mathrm{Y}_{\mathrm{obs}}$ value was lower.

In a mean time, high utilization rate of the substrate (i.e. soy sauce wastewater) in R3 and R1 was achieved. In addition, the $\mathrm{Y}_{\mathrm{obs}}$ value was increased as the SRT was decreased. This is referred as the sludge production in the wastewater treatment plant increased with decrease of the sludge age [29]. Y value in $24 \mathrm{~h}$ of HRT was the lowest compared to other reactors. The result demonstrated that low biomass was produced in the reactor but higher in rate of substrate removal as the $\mathrm{Y}_{\mathrm{obs}}$ value was low with the lowest $\mu_{\text {overall }}$ and $k_{d}$ was achieved. In summary, the kinetic parameters could provide good prediction on the aerobic granular sludge system performances and system design of SBR in treating soy sauce wastewater.

\section{Conclusion}

This results demonstrated that HRT could affected the physical properties of the reactor, physical characteristic of aerobic granular sludge and the biokinetics. Highest HRT (24h) promoted the formation of the highest mean size of aerobic granular sludge with diameter of $2.2 \pm 0.1 \mathrm{~mm}$. The granular biomass concentration in the reactor improved which is mainly due to the increase in the OLR. Moreover, longest SRT was observed (8.53 \pm 1.8 days), which would lower the specific bacteria growth rate. As the aerobic granules developed, the small granules still coexisted with the large granules in all reactors. Meanwhile, the biomass decay rate in the system $\left(\mathrm{k}_{\mathrm{d}}\right)$ and biomass yield $(\mathrm{Y})$ was low. From the study, sludge age, $\mu_{\text {overall }}$ and granules sludge production of were greatly influenced by the HRT. The highest HRT resulted in the highest of sludge age with the lowest of biomass growth rate and sludge production in the system. These findings represent important information about the best HRT and the reaction time of aerobic and anaerobic/anoxic that is crucial to improve the performances of aerobic granulation in treating soy sauce wastewater.

\section{Acknowledgement}

The authors wish to thank Universiti Tun Hussein Onn Malaysia for the financial support of this research (TIER 1 Research Grant grant code $\mathrm{H} 125$ ) 


\section{References}

[1] McSorley, C.A., Wagnitz, D.R., Sasaki, S. and Olson, B. (2004) Improvement in treatment efficiency of a soybean fermentation wastewater treatment plant by the addition of an enzyme-surfactant mixture. EcoCatalysts. 1, 1-12.

[2] Ge, H., Batstone, D. J., \& Keller, J. (2013). Operating aerobic wastewater treatment at very short sludge ages enables treatment and energy recovery through anaerobic sludge digestion. Water research, 47(17), 6546-6557.

[3] Rosman, N. H. (2014). Efficiency of aerobic granulation technology in treating high strength soy sauce wastewater. Sains Malays, 43, 1485-1490.

[4] Cheng, K., Hu, J., Hou, H., Liu, B., Chen, Q., Pan, K., \& Yang, C. (2017). Aerobic granular sludge inoculated microbial fuel cells for enhanced epoxy reactive diluent wastewater treatment. Bioresource technology, 229, 126-133.

[5] Chen, Y.F., Ng, W.J. and Yap, M.G.S. (1994). Performance of upflow anaerobic biofilter process in pharmaceutical wastewater treatment. Resources, Conservation and Recycling. 11(1), 83-91.

[6] Pan, S., Tay, J.H., He, Y.X. and Tay, S.L. (2004). The effect of hydraulic retention time on the stability of aerobically grown microbial granules. Letters in Applied Microbiology. 38(2), 158 163.

[7] Gao, D., Liu, L., Liang, H. and Wu, W.M. (2011). Aerobic granular sludge: characterization, mechanism of granulation and application to wastewater treatment. Critical Reviews in Biotechnology. 31(2), 137-152.

[8] Liu, Y.Q. and Tay, J.H. (2007). Influence of cycle time on kinetic behaviors of steady-state aerobic granules in sequencing batch reactors. Enzyme and Microbial Technology. 41(4), 516-522.

[9] American Public Health Association. APHA. 2005. Standard Methods for the Examination of Water and Wastewater. 21st ed. American Public Health Association, Washington DC, 1220p.

[10] Muda, K., Aris, A., Salim, M.R., Ibrahim, Z., van Loosdrecht, M.C.M, Ahmad, A. and Nawahwi, M.Z. (2011). The effect of hydraulic retention time on granular sludge biomass in treating textile wastewater. Water Research. 45(16), 4711-4721.

[11] Rojas-Z, U., Fajardo-O, C., Moreno-Andrade, I., \& Monroy, O. (2017). Greywater treatment in an aerobic SBR: sludge structure and kinetics. Water Science and Technology, wst2017341.

[12] Filali, A., Manas, A., Mercade, M., Bessiere, Y., Biscans, B. and Sperandio, M. (2012). Stability and performance of two GSBR operated in alternating anoxic/aerobic or anaerobic/aerobic conditions for nutrient removal. Biochemical Engineering Journal. 67, 10-19.

[13] Liu, Y. and Liu, Q.S. (2006). Causes and control of filamentous growth in aerobic granular sludge sequencing batch reactors. Biotechnology Advances. 24(1), 115-127.

[14] Kargi, F. and Uygur, A. (2002). Nutrient removal performance of a sequencing batch reactor as a function of the sludge age. Enzyme and Microbial Technology. 31(6). 842-847.

[15] Yong, L.I. (2009). Kinetic and metabolic behaviors of aerobic granules developed in sequencing batch reactors. Ph.D Thesis. Nanyang Technological University.

[16] Ni, B.J. and Yu, H.Q. (2008). Storage and growth of denitrifiers in aerobic granules: Part I. Model development. Biotechnology and Bioengineering. 99(2), 314-323.

[17] Obaja, D., Mace, S. and Mata-Alvarez, J. (2005). Biological nutrient removal by a sequencing batch reactor (SBR) using an internal organic carbon source in digested piggery wastewater. Bioresource Technology. 96(1), 7-14

[18] Ni, B.J., Yu, H.Q. and Sun, Y.J. (2008). Modeling simultaneous autotrophic and heterotrophic growth in aerobic granules. Water Research. 42(6), 1583-1594.

[19] Rosman, N.H., Anuar, A.N., Chelliapan, S., Din, M.F.M. and Ujang, Z. (2014). Characteristics and performance of aerobic granular sludge treating rubber wastewater at different hydraulic retention time. Bioresource Technology. 161, 155-161.

[20] Li, Z.H., Kuba, T. and Kusuda, T. (2006). Selective force and mature phase affect the stability of aerobic granule: An experimental study by applying different removal methods of sludge. Enzyme and Microbial Technology. 39(5), 976-981.

[21] Long, B., Yang, C.Z., Pu, W.H., Yang, J.K., Jiang, G.S., Dan, J.F., Li, C.Y. and Liu, F.B. (2014). Rapid cultivation of aerobic granular sludge in a pilot scale sequencing batch reactor. Bioresource Technology. 166, 57-63.
[22] Zhang, Y., Wang, X., Hu, M. and Li, P. (2015). Effect of hydraulic retention time (HRT) on the biodegradation of trichloroethylene wastewater and anaerobic bacterial community in the UASB reactor. Applied Microbiology and Biotechnology. 99(4), $1977-$ 1987.

[23] Tay, J.H., Liu, Q.S. and Liu, Y. (2002a). Aerobic granulation in sequential sludge blanket reactor. Water Science and Technology. 46(4-5), 13-18.

[24] Soltani, R., Rezaee, A., Godini, H., Khataee, A.R. and Jorfi, S. (2013). Organic matter removal under high loads in a fixed-bed sequencing batch reactor with peach pit as carrier. Environmental Progress and Sustainable Energy. 32(3), 681-687.

[25] Liu, Y.Q. and Tay, J.H. (2007). Influence of cycle time on kinetic behaviors of steady-state aerobic granules in sequencing batch reactors. Enzyme and Microbial Technology. 41(4), 516-522.

[26] Moy, B.P., Tay, J.H., Toh, S.K., Liu, Y. and Tay, S.L. (2002). High organic loading influences the physical characteristics of aerobic sludge granules. Letters in Applied Microbiology. 34(6), 407-412.

[27] Zheng, Y.M., Yu, H.Q., Liu, S.J. and Liu, X.Z. (2006). Formation and instability of aerobic granules under high organic loading conditions. Chemosphere. 63(10), 1791-1800.

[28] Gao, D.W., Liu, L. and Liang, H. (2013). Influence of aeration intensity on mature aerobic granules in sequencing batch reactor. Applied Microbiology and Biotechnology. 97(9), 4213-4219.

[29] Chen, Y., Jiang, W., Liang, D.T. and Tay, J H. (2008). Biodegradation and kinetics of aerobic granules under high organic loading rates in sequencing batch reactor. Applied Microbiology and Biotechnology. 79(2), 301-308 